\title{
A Nanocomposite of Graphitic Carbon Nitride and Carbon Dots as a Platform for Sensitive Voltammetric Determination of 2- chlorophenol in Water
}

\author{
Theo H.G. Moundzounga ${ }^{1}$, Moses G. Peleyeju ${ }^{1 *}$, Saheed O. Sanni, Michael J. Klink ${ }^{1,2}$, \\ Ekemena Oseghe ${ }^{3}$, Elvera Viljoen ${ }^{1}$, Augustine E. Ofomaja \\ ${ }^{1}$ Department of Chemistry, Vaal University of Technology, Andries Potgieter Boulevard, \\ Vanderbijlpark, 1911, South Africa \\ ${ }^{2}$ Biotechnology, Vaal University of Technology, Andries Potgieter Boulevard, Vanderbijlpark, 1911, \\ South Africa \\ ${ }^{3}$ School of Science, Engineering and Technology, Nanotechnology and Water Sustainability \\ (NanoWS) Reserach Unit, University of South Africa, Johannesburg, South Africa. \\ *E-mail: $\underline{\text { mgpeleyeju@gmail.com, mosesp@ vut.ac.za }}$
}

doi: $10.20964 / 2021.05 .15$

Received: 20 December 2020 / Accepted: 8 February 2021 / Published: 31 March 2021

\begin{abstract}
Herein, we report the preparation, characterisation and application of graphitic carbon nitride/carbon nanodots nanocomposite $\left(\mathrm{g}-\mathrm{C}_{3} \mathrm{~N}_{4} / \mathrm{CDs}\right.$ ) as a platform for the sensing of 2-chlorophenol in water. The g$\mathrm{C}_{3} \mathrm{~N}_{4} / \mathrm{CDs}$ was prepared via microwave irradiation and characterised by transmission electron microscopy (TEM), Fourier transform infrared spectroscopy (FTIR) and X-ray diffraction (XRD). The electrochemical properties of modified glassy carbon electrodes were studied using cyclic voltammetry (CV). In comparison to unmodified GCE, there was a marked enhancement of the oxidation peak of the analyte when GCE modified with the nanocomposite material was used. The composite modifier also performed better than the single-component modifiers. The oxidation peak currents varied linearly with the concentrations in the range 0.5 to $2.5 \mu \mathrm{M}$ with a detection limit of $0.67 \mu \mathrm{M}$. The sensor was used to determine the analyte in real water samples with good recoveries.
\end{abstract}

Keywords: Graphitic carbon nitride, Carbon nanodots, 2-Chlorophenol, Electrode modifiers, Electroanalysis.

\section{FULL TEXT}

(C) 2021 The Authors. Published by ESG (www.electrochemsci.org). This article is an open access article distributed under the terms and conditions of the Creative Commons Attribution license (http://creativecommons.org/licenses/by/4.0/). 